\title{
Article \\ Conducting an International, Exploratory Survey to Collect Data on Honey Bee Disease Management and Control
}

\author{
Ziad Mezher ${ }^{1, *}$, Jernej Bubnic ${ }^{2}{ }^{\mathbb{D}}$, Roberto Condoleo ${ }^{1}$, Filippo Jannoni-Sebastianini ${ }^{3}$, Andrea Leto ${ }^{1}$, \\ Francesco Proscia ${ }^{4}$ and Giovanni Formato ${ }^{1}$ \\ 1 Istituto Zooprofilattico Sperimentale del Lazio e Della Toscana "M. Aleandri", 00178 Rome, Italy; \\ roberto.condoleo@izslt.it (R.C.); andrea.leto@izslt.it (A.L.); giovanni.formato@izslt.it (G.F.) \\ 2 Agriculture Institute of Slovenia, SI-1000 Ljubljana, Slovenia; jernej.bubnic@kis.si \\ 3 International Federation of Beekeepers' Associations (Apimondia), 00186 Rome, Italy; apimondia@mclink.it \\ 4 Federation of Veterinarians of Europe (FVE), B-1040 Brussels, Belgium; francesco@fve.org \\ * Correspondence: ziad.mezher@izslt.it
}

Citation: Mezher, Z.; Bubnic, J.;

Condoleo, R.; Jannoni-Sebastianini, F.; Leto, A.; Proscia, F.; Formato, G.

Conducting an International,

Exploratory Survey to Collect Data on Honey Bee Disease Management and Control. Appl. Sci. 2021, 11, 7311. https://doi.org/10.3390/app11167311

Academic Editor: Dimitris Mossialos

Received: 8 July 2021

Accepted: 4 August 2021

Published: 9 August 2021

Publisher's Note: MDPI stays neutral with regard to jurisdictional claims in published maps and institutional affiliations.

Copyright: (c) 2021 by the authors. Licensee MDPI, Basel, Switzerland. This article is an open access article distributed under the terms and conditions of the Creative Commons Attribution (CC BY) license (https:// creativecommons.org/licenses/by/ $4.0 /)$.

\begin{abstract}
The Istituto Zooprofilattico Sperimentale del Lazio e della Toscana (IZSLT) and the International Federation of Beekeepers' Associations (Apimondia) set up a worldwide survey in 2015-2017 to gather information on beekeepers' perceptions concerning good beekeeping practices, the main honey bee diseases, and the technical assistance they receive. The on-line dissemination of the survey was facilitated by the "Technologies and Practices for Small Agricultural Producers" platform (TECA) of the Food and Agriculture Organization of the United Nations (FAO). In total, 248 questionnaires were received from the European region and the results are reported here. Varroosis remains the biggest concern and is the most important reason for beekeepers' use of veterinary medicines. However, a sustainable approach to managing Varroa was detected. American foulbrood (AFB) and European foulbrood (EFB) infections are mainly managed through the shook swarm technique or burning the hives. Concerning technical assistance for disease management, beekeepers were mainly supported by their associations or expert beekeepers. Relevant data were collected and analyzed but information from many low-income countries in Africa or Asia is still missing, and more efforts are needed to fill the knowledge gaps.
\end{abstract}

Keywords: online survey; beekeeping; veterinary medicines; honey bee diseases; good beekeeping practices

\section{Introduction}

Modern beekeeping suffers significant losses worldwide due to a variety of external stressors, including pesticide misuse, climate change, globalization of honey bee diseases and pests, loss of bee fodder, conventional monocultures, overbuilding and mistakes in hive and disease management [1-5].

In recent years, new issues concerning the beekeeping sector have also been documented, such as the spread of new invasive alien species (Vespa velutina, Nosema ceranae, Aethina tumida) and an increase in the pathogenicity of already known pathogens, such as the viruses related to Varroa destructor [6-10].

In this complex situation, guaranteeing both honey bee health and successful beekeeping activity is often quite arduous. Furthermore, in most countries, veterinarians usually lack the minimum competencies required to enable them to provide helpful support to beekeepers [11]. The availability of only a few veterinary medicinal products (VMPs) (EU Veterinary Medicinal Product Database, accessed on 9 January 2020) further complicates the situation. As a result, all these factors can lead to inadequate control of honey bee diseases, misuse of veterinary medicines, or in the worst cases, illegal use of unauthorized drugs.

In the apiculture sector, as in others, the intensive use of the same active ingredients over the years has led to the development of veterinary drug resistance, especially in 
the Varroa mite $[12,13]$. As a direct consequence, there has been either a reduction in the efficacy (and choices) of available treatments or an increase in chemical residues in hive products [14-17].

Nowadays, modern apiculture requires the adoption of Good Beekeeping Practices (GBPs) in order to prevent and control, in the best way possible, honey bee diseases and allow the proper use of VMPs. In this context, the adequate training of beekeepers as well as veterinarians and the application of an integrated pest management (IPM) strategy, which is defined by the Food and Agriculture Organization of the United Nations (FAO) as: "The careful consideration of all available pest control techniques and subsequent integration of appropriate measures that discourage the development of pest populations and keep pesticides and other interventions to levels that are economically justified and reduce or minimize risks to human health and the environment", play a vital role in the achievement of good honey bee colony management. In particular, this means the adoption of different beekeeping techniques and biotechnical methods in combination with veterinary medicines [16]. A good understanding of honey bee biology and pathogens is also required in order to incorporate the IPM strategy into daily activities.

However, there is a general lack of information about beekeepers' knowledge, level of training and application of GBPs to manage and control honey bee diseases and data are missing from large geographical areas.

For these reasons, a questionnaire-based survey was developed and promoted with the purpose of filling the gaps by collecting specific information from target professions around the world including: (1) knowledge of the most important honey bee diseases and their management; (2) use of VMPs in beekeeping; and (3) perceptions about the role of veterinarians, training and technical assistance in the management of honey bee diseases.

The online questionnaire, "Veterinary medicines in beekeeping around the world: which active ingredients are in use and do they respond to the needs of beekeepers?" was set up by the Istituto Zooprofilattico Sperimentale del Lazio e della Toscana "M. Aleandri" (IZSLT), and the International Federation of Beekeepers' Associations (Apimondia). The on-line dissemination of the survey was facilitated by the "Technologies and Practices for Small Agricultural Producers" (TECA) platform of the FAO [18].

In this paper, we present the most relevant results of the survey from European participants together with the considerations involved in this unique experience.

\section{Materials and Methods}

SurveyMonkey ${ }^{\circledR}$ was used to implement the online questionnaire and collect the data. It was made available in four languages (English, French, Italian and Spanish) and was promoted in three different periods (of about two months each) between 2015 and 2017. The target groups were: beekeepers, veterinarians, beekeeping inspectors/technicians, beekeeping teachers/trainers, researchers in the beekeeping sector and employees of governmental institutions involved in beekeeping. Various channels were used to promote and distribute the survey, mainly through the TECA website and outreach activities and direct invitation by e-mails. The link to the survey was also published on a IZSLT specific webpage dedicated to apiculture and people from the target categories were invited to participate [19].

Participation in the survey was anonymous and a mechanism was introduced to prevent users from submitting the questionnaire more than once.

The questionnaire was preceded by a set of three closed questions that aimed to classify participants based on (a) their geographical location, (b) profession (see target groups above) and (c) number of hives they possessed (Table 1). Based on this last question the beekeeper category was divided into two sub-categories: those with less than 30 hives were considered hobby beekeepers while those with more than 30 hives were considered professional beekeepers. 
Table 1. Structure of the questionnaire: questions are divided into three main parts $\mathrm{A}, \mathrm{B}$ and $\mathrm{C}$; type of questions $(\mathrm{Sm})^{1}=$ Semi-closed, $(\mathrm{Cl})^{2}=$ Closed, $(\mathrm{Oe})^{3}=$ Open-ended.

\begin{tabular}{|c|c|c|}
\hline Letter/Number & Question, (Type of Question) & Part/Section \\
\hline a & In which region are you located? & - \\
\hline $\mathrm{b}$ & Select your profession among the following: & - \\
\hline c & How many beehives do you have? & - \\
\hline 1 & What diseases have you already heard about? (Sm) & A \\
\hline 2 & $\begin{array}{c}\text { Can you give a score to each disease according to its impact on the } \\
\text { honeybee health in your apiary? (Sm) }\end{array}$ & A \\
\hline 3 & $\begin{array}{l}\text { Do you have other information you want to share about diseases affecting } \\
\text { beekeeping in your country (personal experience, global impact, evolution } \\
\text { in the last years, etc.)? (Oe) }\end{array}$ & A \\
\hline 4 & $\begin{array}{l}\text { Do you think that observing good beekeeping practices alone, without the } \\
\text { use of active ingredients or medicines, could guarantee the health of your } \\
\text { hives (regarding the following diseases)? (Sm) }\end{array}$ & A \\
\hline 5 & $\begin{array}{l}\text { Do you think that veterinary medicines are necessary in apiculture to } \\
\text { guarantee the health of your hives (regarding the following diseases)? (Sm) }\end{array}$ & A \\
\hline 6 & Have you ever seen a Varroa mite? $(\mathrm{Cl})$ & $\mathrm{B}$ \\
\hline 7 & $\begin{array}{l}\text { Which are the active ingredients you normally use in your apiary in the } \\
\text { treatment against Varroa? (Sm) }\end{array}$ & B \\
\hline 8 & $\begin{array}{l}\text { Before treating your hives against Varroa, do you check the level of } \\
\text { infestation (mite count)? (Cl) }\end{array}$ & $\mathrm{B}$ \\
\hline 9 & $\begin{array}{c}\text { If not yet available, which active ingredients would you like to have in } \\
\text { your country as registered and authorized ingredients? }(\mathrm{Sm})\end{array}$ & B \\
\hline 10 & Have you ever seen brood affected by AFB? $(\mathrm{Cl})$ & B \\
\hline 11 & Are you able to diagnose AFB in your hives? $(\mathrm{Cl})$ & B \\
\hline 12 & How did you diagnose AFB in you hives? (Sm) & $\mathrm{B}$ \\
\hline 13 & Which method do you think is the best to manage AFB? (Sm) & B \\
\hline 14 & What product is currently available in your country to treat AFB? (Sm) & $\mathrm{B}$ \\
\hline 15 & $\begin{array}{l}\text { Do you think the products currently available in your country to treat AFB } \\
\text { are effective? }(\mathrm{Cl})\end{array}$ & B \\
\hline 16 & Have you ever seen brood affected by EFB? $(\mathrm{Cl})$ & B \\
\hline 17 & Are you able to diagnose EFB in your hives? $(\mathrm{Cl})$ & $\mathrm{B}$ \\
\hline 18 & How did you diagnose EFB in you hives? (Sm) & B \\
\hline 19 & Which method do you think is the best to manage EFB? (Sm) & B \\
\hline 20 & What product is currently available in your country to treat EFB? (Sm) & $\mathrm{B}$ \\
\hline 21 & $\begin{array}{l}\text { Do you think the products currently available in your country to treat EFB } \\
\text { are effective? }(\mathrm{Cl})\end{array}$ & $\mathrm{B}$ \\
\hline 22 & How did you develop your beekeeping skills? (Sm) & $\mathrm{C}$ \\
\hline 23 & $\begin{array}{l}\text { Are you well informed about the organization of beekeeping } \\
\text { courses/meetings held in your region? }(\mathrm{Sm})\end{array}$ & $\mathrm{C}$ \\
\hline 24 & $\begin{array}{l}\text { Do you think you receive appropriate technical assistance for your needs } \\
\text { in the apiary treatments? (Sm) }\end{array}$ & $\mathrm{C}$ \\
\hline 25 & $\begin{array}{l}\text { What amount of assistance would you need in your apiary for honeybee } \\
\text { diseases/apiary management? }(\mathrm{Cl})\end{array}$ & $C$ \\
\hline 26 & $\begin{array}{l}\text { What amount of assistance do you actually get in your apiary for honeybee } \\
\text { diseases/apiary management? }(\mathrm{Cl})\end{array}$ & C \\
\hline
\end{tabular}


Table 1. Cont.

\begin{tabular}{|c|c|c|}
\hline Letter/Number & Question, (Type of Question) & Part/Section \\
\hline 27 & Where do you get assistance about apiary treatments? (Sm) & $\mathrm{C}$ \\
\hline 28 & $\begin{array}{c}\text { Do you think veterinarians are sufficiently informed on the honeybee } \\
\text { diseases and the related treatments? }(\mathrm{Sm})\end{array}$ & $\mathrm{C}$ \\
\hline 29 & $\begin{array}{l}\text { Do you think you are well informed about the good beekeeping practices } \\
\text { to apply at the apiary level? (Sm) }\end{array}$ & $\mathrm{C}$ \\
\hline 30 & $\begin{array}{l}\text { Do you consider effective the veterinary products available in your country } \\
\text { to treat the following hive diseases? }(\mathrm{Sm})\end{array}$ & $\mathrm{C}$ \\
\hline 31 & Do you buy veterinary medicines, to treat the following diseases? (Sm) & $\mathrm{C}$ \\
\hline 32 & Do you use homemade medicines to treat the following diseases? (Sm) & $\mathrm{C}$ \\
\hline 33 & Have you already noticed lack of efficacy of treatments? $(\mathrm{Cl})$ & $\mathrm{C}$ \\
\hline 34 & $\begin{array}{l}\text { Which active ingredients do you think are no longer effective (e.g., because } \\
\text { of resistance)? (Sm) }\end{array}$ & $\mathrm{C}$ \\
\hline 35 & $\begin{array}{l}\text { What do you think could be done to improve the efficacy of the available } \\
\text { treatments? (Oe) }\end{array}$ & $\mathrm{C}$ \\
\hline 36 & $\begin{array}{l}\text { Do you think you need new active ingredients against honeybee diseases? } \\
\qquad(\mathrm{Cl})\end{array}$ & $\mathrm{C}$ \\
\hline 37 & Which new active ingredients would you need against Varroa? (Sm) & $\mathrm{C}$ \\
\hline 38 & Which new active ingredients would you need against AFB? (Sm) & $\mathrm{C}$ \\
\hline 39 & Which new active ingredients would you need against EFB? (Sm) & $\mathrm{C}$ \\
\hline 40 & Which new active ingredients would you need against Nosema? (Sm) & $\mathrm{C}$ \\
\hline 41 & $\begin{array}{l}\text { Which new active ingredients would you need against Tracheal mite } \\
\qquad \text { (Acarapis woodi)? (Sm) }\end{array}$ & $\mathrm{C}$ \\
\hline 42 & $\begin{array}{l}\text { Which new active ingredients would you need against Small hive beetle } \\
\qquad(\text { Aethina tumida)? (Sm) }\end{array}$ & $\mathrm{C}$ \\
\hline 43 & Which new active ingredients would you need against Tropilaelaps? (Sm) & $\mathrm{C}$ \\
\hline 44 & $\begin{array}{c}\text { Which new active ingredients would you need against Myiasis of } \\
\text { honeybees (e.g., Senotainia tricuspis)? (Sm) }\end{array}$ & $\mathrm{C}$ \\
\hline 45 & $\begin{array}{c}\text { Which new active ingredients would you need against any other diseases } \\
\text { that were not mentioned in this survey? (Oe) }\end{array}$ & $\mathrm{C}$ \\
\hline
\end{tabular}

A list of 13 different geographical areas covering all the continents was used to identify the user's location.

The core part of the questionnaire consisted of 45 questions (Table 1 ), most of which were semi-closed $(67 \%)$ or closed $(27 \%)$ with just a few open-ended questions $(6 \%)$, and was divided into three parts each investigating specific aspects of beekeeping. Part " $\mathrm{A}$ " (5 questions) aimed to gather general information on the perceptions regarding honey bee diseases, the proper management of the hives and the use of medicines; part "B" (16 questions) aimed to assess specific knowledge about the prevention and control measures adopted by the participants against Varroa, American foulbrood (AFB) and European foulbrood (EFB); and part " $\mathrm{C}$ " (24 questions) aimed to collect information concerning the kind of assistance available to beekeepers, their perceptions about the efficacy of treatments and the need for new VMPs.

All responses from participants were tabulated and the basic data analysis and presentation was achieved using Microsoft Excel spreadsheets (Microsoft ${ }^{\circledR}$, Redmond, Washington, DC, USA). Graphs were prepared for each question of the survey using percentages 
or weighted averages, according to the type of collected data. In particular, a modified equation was used to calculate the weighted arithmetic means (Figure 1) in order to take the variations in the total number of answers for each disease into consideration:

$$
\frac{\sum_{i=1}^{n} w_{i} * \frac{x_{i}}{T_{d}}}{\sum_{i=1}^{n} w_{i}}
$$

where: $w_{i}=$ Weight assigned to the disease impact parameter $(i) ; T_{d}=$ Total number of answers from participants for disease $(d) ; x_{i}=$ Number of participants who chose the parameter $(i)$ for the disease $(d)$.

\begin{tabular}{cc}
\hline Disease impact parameters & Weight \\
\hline Very severe & 5 \\
\hline Severe & 4 \\
\hline Moderate & 3 \\
\hline Low impact & 2 \\
\hline No impact & 1 \\
\hline
\end{tabular}

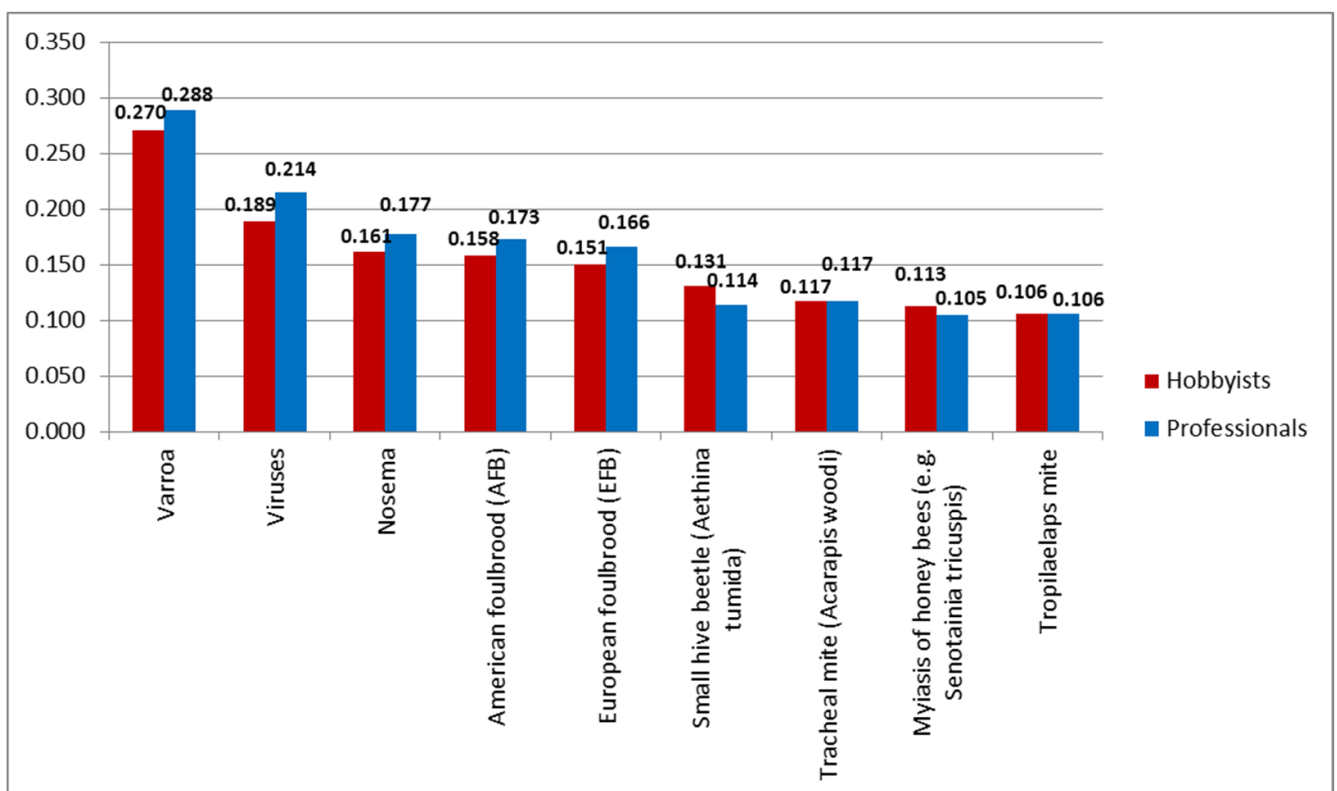

Figure 1. Disease scoring (weighted means) according to its impact on honey bee health.

\section{Results}

In total, 403 questionnaires were received; $41.9 \%$ of participants used the English version of the survey, $39 \%$ used the Italian one, and $11.9 \%$ and $7.2 \%$ used the French and Spanish versions, respectively.

With regard to the geographical distribution of participants, $74.7 \%(301 / 403)$ were from the European continent whereas 25.3\% (102/403) were from non-European countries (mainly Northern America, Australia and New Zealand).

Among all the targeted professions, most participants were beekeepers $(323 / 403,80 \%)$ or veterinarians $(62 / 403,15 \%)$.

Here, we report only the data received from beekeepers in the European region ( 248 questionnaires) as data from other very large and diverse geographical regions of the globe represented a small percentage of the received questionnaires.

In this category, $38 \%$ of the participants $(95 / 248)$ were professional beekeepers while $62 \%$ were hobby beekeepers $(153 / 248)$. 
3.1. Part A. "General Information about the Honey Bee Diseases, the Proper Management of the Hives and the Use of Medicines"

The majority of beekeepers (mean, 93.04\%) knew about the main honey bee diseases (especially Varroa, nosema, AFB and EFB) but they were less aware of minor or less known honey bee diseases (such as tracheal mite, Tropilaelaps or myiasis).

Varroa was considered the most important disease affecting honey bee health, followed by viral diseases and nosema (Figure 1). The modified weighted mean equation was used for the calculation.

According to $78.6 \%$ of hobby and $77.4 \%$ of professional beekeepers, the adoption of good beekeeping practices alone, without the use of any active ingredients or medicines, is fully or partially sufficient to control nosema, EFB, tracheal mite, AFB and viral diseases. On the contrary, $85.1 \%$ of hobby beekeepers and $93.7 \%$ of professionals think that the application of veterinary medicines is indispensable for controlling Varroa.

\subsection{Part B. "Assessment of Specific Knowledge about the Prevention and Control Measures Adopted for Varroa, AFB and EFB"}

The survey showed that $71.3 \%$ of hobby and $72.8 \%$ of professional beekeepers use organic acids (formic acid, oxalic acid, lactic acid) for the control of Varroa while $45.3 \%$ and $45.7 \%$, respectively, also rely on the application of mechanical methods (e.g., queen caging and brood removal). Four percent of hobby beekeepers ( $0 \%$ of professionals) do not use any type of Varroa control measures.

Concerning the monitoring of Varroa infestation levels, almost half ( $48 \%$ ) of the hobby beekeepers and 38\% of professional beekeepers in Europe always check such levels prior to treatment. On the other hand, $11.3 \%$ of hobby and $15.2 \%$ of professional beekeepers consider such an approach unnecessary, and therefore, they never monitor the parasite.

Regarding the diagnosis of AFB and EFB, $74.9 \%$ and $91.7 \%$ of hobby and professional beekeepers, respectively, declared that they are able to identify the visible signs of the diseases by themselves. Less than $27.8 \%$ of hobby beekeepers and less than $22 \%$ of professional beekeepers rely on laboratory tests to confirm the diagnosis of these microbial infections while the use of on-field kits varied between $16.7 \%$ and $27.5 \%$ in both categories. Showing the sample to a more experienced beekeeper in case of doubt or consulting with veterinarians were the least adopted options (percentages varied and were below 15.2\%).

The "shook swarm" technique was considered the best method to manage EFB or AFB (only hobby beekeepers). The destruction of the affected colonies was also one of the preferred strategies for both diseases (especially for professional beekeepers). Between $1 \%$ and $10 \%$ of beekeepers consider the application of antibiotics, alone or in combination with the shook swarm technique, as a valid method for the control of such bacterial diseases (Figures 2 and 3). On the contrary, between $13.2 \%$ and $28.1 \%$ of beekeepers do not know how to manage such diseases. 


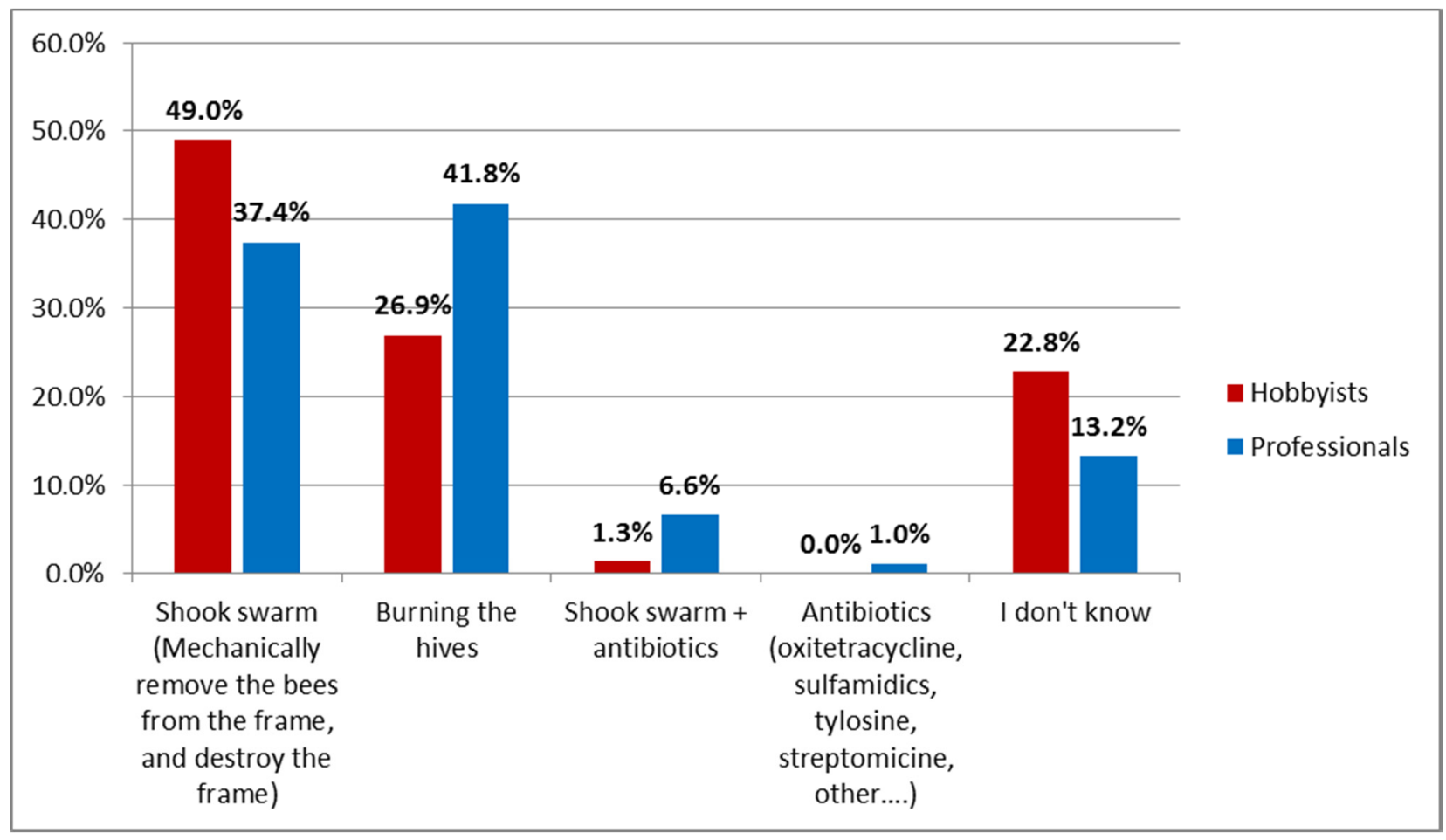

Figure 2. The best method to manage AFB.

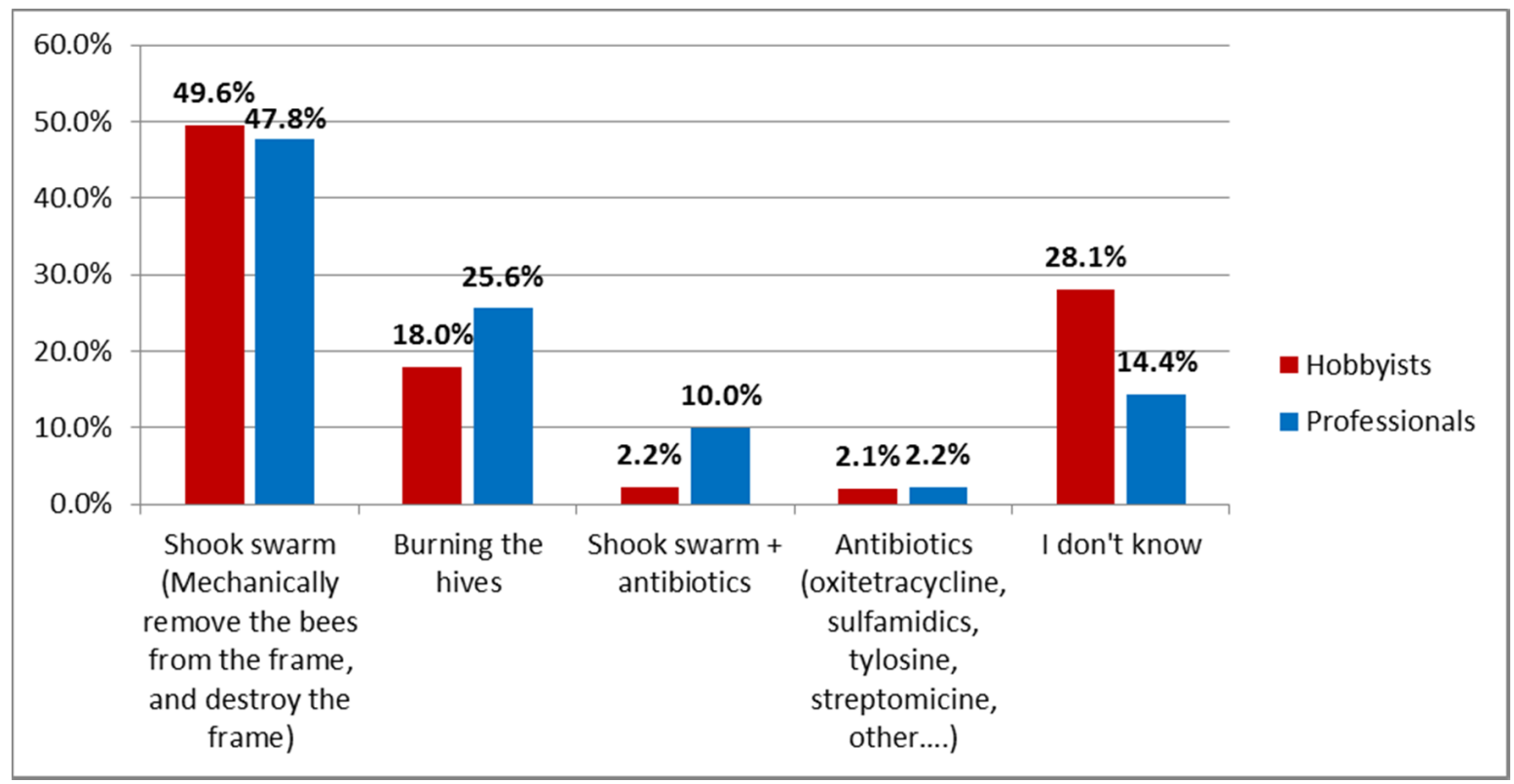

Figure 3. The best method to manage EFB.

3.3. Part C. "The Kind of Assistance Beekeepers Receive, Their Impressions of the Efficacy of Treatments and the Need for New VMPs"

In total, $66.4 \%$ (mean) of beekeepers have developed their beekeeping skills (Figure 4 ) through: (1) participation in beekeeping courses or working/training with expert beekeepers; (2) self-study using websites, reading books or forums; and (3) courses or visits to apiaries organized by the beekeepers' associations.

However, governmental initiatives (leaflets, guidelines, technical assistance), or the web platforms of international organizations (e.g., FAO-TECA) were poorly used. 


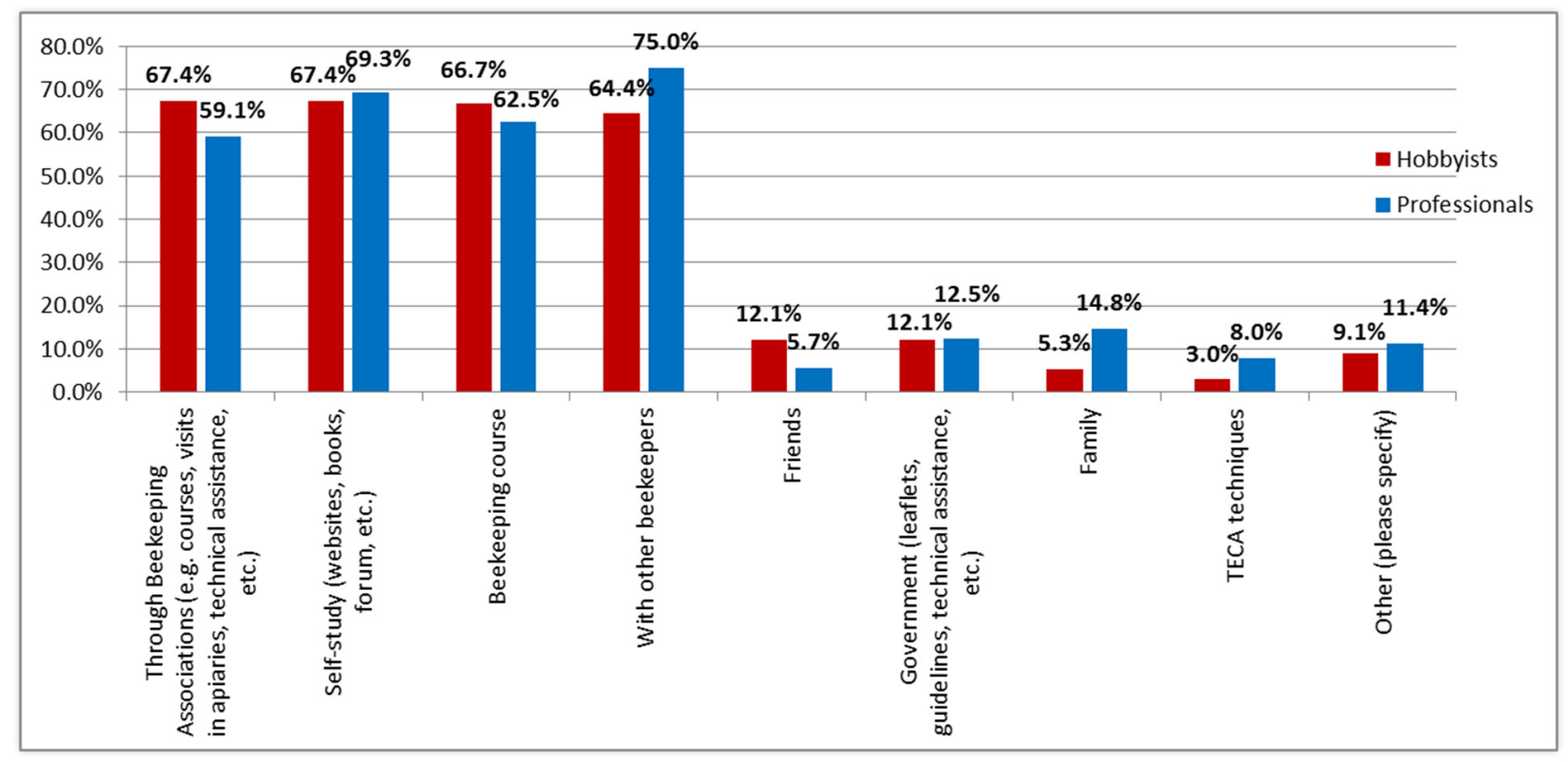

Figure 4. How beekeepers developed their skills.

The results showed that $73.4 \%$ of hobby beekeepers and $78.4 \%$ of professional beekeepers declared they were well informed about the good beekeeping practices that should be applied at the apiary level. The main sources of assistance concerning the control of honey bee diseases were the beekeepers' associations and cooperatives (38.6\% of hobby and $45.5 \%$ professional beekeepers), followed by expert beekeepers ( $28 \%$ of hobby and $27.3 \%$ of professional beekeepers), and to a lesser extent, veterinarians ( $15.9 \%$ and $18.2 \%$ of the surveyed hobby and professional beekeepers, respectively). Around one-third (30.3\%) of hobby beekeepers and $25.0 \%$ of professional beekeepers declared they did not receive any kind of assistance at all. A total of $56 \%$ of hobby beekeepers and $63.6 \%$ of professional beekeepers consider that veterinarians are not sufficiently informed about the main honey bee diseases and related treatments. Concerning Varroa, $49.2 \%$ of hobby and $50 \%$ of professional beekeepers consider that the available veterinary medicine products are only partially effective against the mite. The lack of efficacy of treatments was mainly ascribed to thymol and fluvalinate (Figure 5).

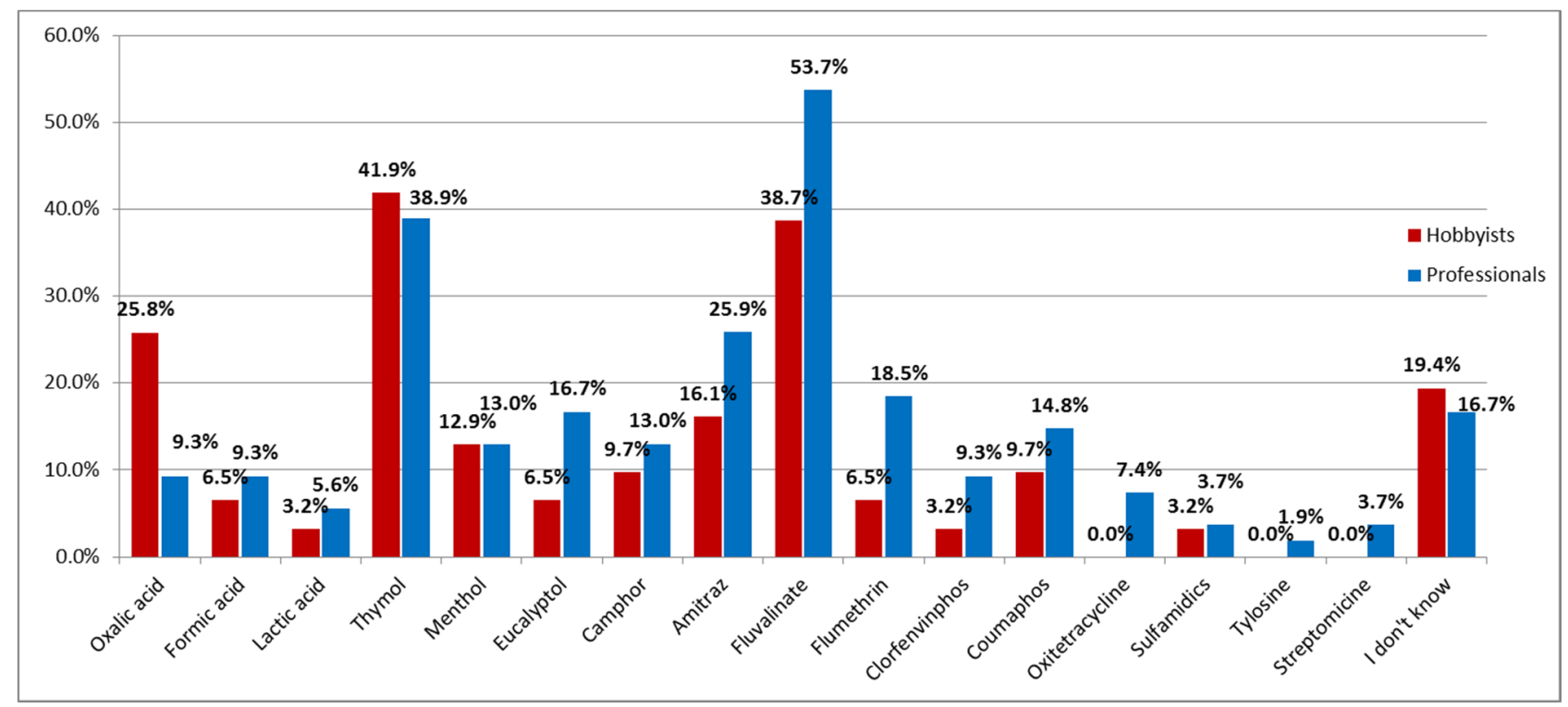

Figure 5. VMPs' active ingredients no longer effective according to surveyed beekeepers. 
Finally, the most frequently used veterinary medicines in beekeeping were those against Varroa ( $86.4 \%$ for hobby and $88.6 \%$ for professional beekeepers).

\section{Discussion}

The scope of the survey presented here was to collect worldwide data on essential aspects of the beekeeping sector, mainly concerning the application of good beekeeping practices, the use of veterinary medicines and the technical support and training provided to beekeepers, in order to reduce the gap in knowledge and contribute to the dissemination of vital information among stakeholders. Attempts to collect this data were made on three different occasions through the on-line promotion of the questionnaire in collaboration with international institutions and beekeeping organizations. We interviewed people involved in the beekeeping sector ( $80 \%$ of the participants were beekeepers and $15 \%$ veterinarians), however, most of them were from Europe while wide geographic areas such as Africa and Asia remained almost completely unexplored. The low participation from medium and low-income areas might be due to the lack of or limited access to the internet or to a computer, language barriers, and/or difficulties in reaching beekeepers. Other surveys in apiculture have been more successful in terms of participants, such as the surveys conducted by COLOSS [20] and by the US Bee Informed Partnership [21], which involved 28,629 and 5725 beekeepers, respectively. However, these surveys mainly focused on colony mortality, included only a few questions on Varroa and queen management, and did not address the main topics reported in our study (prevention and control measures for the main honey bee diseases, the use of medicines, the efficacy of the treatments and the kind of assistance beekeepers receive).

The distinction between hobby and professional beekeepers was made based on the number of hives they owned. There is no internationally recognized and clear definition of these two categories, probably because of the variability in hive production in the different geographical areas; therefore, we decided to set a threshold of 30 hives (based on the authors' experience and perception in relation to the EU context) to differentiate these two categories of beekeepers.

A similar attempt was made in the US for the colony losses survey [21], where they differentiated three categories: backyard beekeepers (1-50 colonies), sideline beekeepers (51-500 colonies) and commercial beekeepers ( $>500$ colonies).

In regards to the general information about honey bee diseases, proper management of the hives and use of medicines (part A of the survey), the majority of beekeepers from both categories are able to recognize and manage (e.g., by proper feeding of the colonies in cases of nosemosis, or by shook swarm in cases of AFB and EFB) most important honey bee diseases (varroosis, AFB and EFB). Varroosis remains the biggest concern for European beekeepers as well as the most important reason for treating colonies with veterinary medicines.

The results regarding the prevention and control measures adopted for Varroa showed that an "organic" approach to its control is prevalent (>70\%) in Europe. The use of biomechanical methods, such as queen caging techniques or brood removal, are used quite frequently $(>45 \%)$ by both categories of beekeepers. This denotes the use of approaches oriented towards sustainable beekeeping, as well as a good understanding of the integrated management of Varroa.

A very small proportion of hobby beekeepers (4\%) do not treat against Varroa. This might be the result of the "natural selection" approach to breeding for Varroa resistance that is gaining popularity among beekeepers in Europe (the so-called "Darwinian beekeeping" approach). This "naive" approach, which was not present among professional beekeepers, may cause, despite its low frequency, a serious threat to all surrounding apiaries by acting as a possible reservoir of the parasite.

Among European beekeepers, significant attention is given to the regular monitoring of Varroa in order to prevent the attainment of too-high infestation levels within the colonies ( $48 \%$ of hobby and $38 \%$ of professionals). However, a small proportion of beekeepers ( $11 \%$ 
of hobby and $15 \%$ of professionals) seem to give more relevance to planned treatments rather than checking the infestation levels.

A total of $74.9 \%$ of hobby and $91.7 \%$ of professional beekeepers declared that they recognize the clinical signs of AFB and EFB and do not rely on laboratory tests for confirmation or differential diagnosis. This is probably to avoid the consequences deriving from the communication of these notifiable diseases to the relevant authorities.

European beekeepers consider that the shook swarm technique is the best method to manage EFB. Similarly, almost half of hobby beekeepers also use the shook swarm technique for AFB. The destruction of the hives by burning is the strategy of choice among professional beekeepers in case of AFB. Indeed, AFB is a much more severe disease than $\mathrm{EFB}$. The shook swarm technique is quite a time-consuming, labor-intensive technique that may be associated with the possibility of relapses (depending on the season and the strength of the colonies), especially in case of AFB. The shook swarm represents the preferred control method for hobby beekeepers, which is probably due to the lower number of hives they have to manage and the consequent higher amount of time they have to invest in curing each colony compared to professional beekeepers.

Less than $10 \%$ of beekeepers, especially professionals, consider the application of antibiotics, alone or in combination with the shook swarm technique, a valid method for the control of these bacterial diseases. The use of antibiotics is considered by most beekeepers as the worst option for managing both foulbrood diseases. This is probably for several reasons: (1) the absence of antibiotics specifically registered for honey bees; (2) the use of antibiotics registered for other animals is only allowed under the application of the cascade system with the direct involvement of a veterinarian; (3) frequent relapses after treatment; and (4) the need for a withdrawal period to avoid the risk of residues in honey [22-25]. The existence of a relevant proportion of beekeepers that still do not know how to manage $\mathrm{AFB}$ and $\mathrm{EFB}$ could be taken into consideration when addressing training programs for European beekeepers.

VMPs against Varroa are considered only partially effective by $50 \%$ of hobby beekeepers and not effective at all by $15.2 \%$ and $19.3 \%$ of hobby and professional beekeepers, respectively. This phenomenon might be partially explained by the development of acaricide resistance in $V$. destructor or by the complexity that can exist in the proper application of varroacide treatments. Acaricide resistance might be induced by the abuse of treatments (e.g., too high dosage or frequency of applications) or by the practice of illegal treatments (e.g., with home-made preparations containing pesticide treatments). In fact, a small proportion of beekeepers (13.6\% of hobbyists and $10.2 \%$ of professionals) never buy veterinary products but completely rely on illegal, homemade treatments, which is forbidden under current EU legislation.

Unfortunately, in the European Union (EU) most of the medicines registered for honey bees are still sold without any veterinary prescription, making their traceability extremely difficult. Moreover, many of the registered products are not easy to use (e.g., reconstituting medicinal solutions starting from powders, or needing specific administration procedures such as sublimation, etc.), or they need particular conditions (e.g., absence of brood, consideration of external temperatures) to reach their optimum efficacy.

The lack of efficacy of treatments was mainly ascribed to fluvalinate and thymol (Figure 5). Long-term application of synthetic miticides may result in the development of resistance [26-31]. Thymol resistance is rarely reported in the scientific literature on bees [32] even though it is undeniable that several other factors might interfere with its final efficacy $[33,34]$. It is very unlikely that new active compounds will be developed for bees, but elementary practices may be applied to boost the efficacy of the treatments, such as the rotation of the active ingredients and the concurrent application of treatments by all beekeepers located in a certain area.

The results showed that among all the medicinal products, varroacides are the most purchased by European beekeepers $(86.4 \%$ for hobby and $88.6 \%$ for professional beekeepers). So far, in the EU, only acaricides are authorized as veterinary medicines for use in 
apiculture [35] and no veterinary medicinal products are registered for bees to control nosemosis and AFB even though several products are (not properly) registered as feed supplements able to reduce those infections.

With regard to the assistance that the European beekeepers receive (part $C$ of the survey), the collected data showed that the majority of beekeepers gain their knowledge through unverified sources instead of verified sources, such as governmental leaflets or TECA techniques.

It is important to note that there is no centralized program for training beekeepers in EU and each Member State defines its own parameters. In most countries, beekeepers' associations in collaboration with universities and research institutes (beekeeping institutes, veterinary institutes, agricultural institutes, etc.) play a key role as they organize different courses for beginners and for experienced beekeepers.

Our data also indicate that the majority of beekeepers (75.9\%) consider themselves well informed about good beekeeping practices. Concerning the assistance for treating diseases, support is mainly provided by the beekeepers' association or by expert beekeepers. Unfortunately, $30.3 \%$ of hobby beekeepers and $25 \%$ of professional beekeepers still do not receive any kind of assistance at all.

Finally, a relevant proportion of beekeepers consider that veterinarians are not sufficiently informed about honey bee diseases and the related treatments $(56 \%$ and $63.6 \%$ of hobby and professional beekeepers respectively) and this should encourage veterinary federations and institutions to provide better training for their professionals in this field.

\section{Conclusions}

The on-line dissemination of the survey, even though it was done in collaboration with international institutions and beekeeping organizations, was very difficult and did not reach the desired goal to gather as much information as possible from large geographical areas. Unfortunately, gaps in the knowledge on the main topics reported in this paper remain in the literature, in particular, in relation to medium and low-income countries in Africa and Asia. Nevertheless, relevant data from European participants were collected and presented here.

Author Contributions: Z.M.: methodology, data curation, writing-original draft, writing-review and editing; J.B.: writing-review and editing; R.C.: data curation, writing-review and editing; F.J.-S.: methodology, resources; A.L.: supervision; F.P.: writing-review and editing; G.F.: conceptualization, methodology, writing-review and editing, supervision. All authors have read and agreed to the published version of the manuscript.

Funding: This research received no external funding.

Institutional Review Board Statement: The study was conducted according to the guidelines of the Declaration of Helsinki.

Informed Consent Statement: Informed consent was obtained from all subjects involved in the study.

Data Availability Statement: Data could be provided contacting authors.

Acknowledgments: The authors thank Charlotte Lietaer from the FAO-TECA beekeeping platform.

Conflicts of Interest: The authors declare no conflict of interest regarding the publication of this article.

\section{References}

1. Li, J.; Qin, H.; Wu, J.; Sadd, B.M.; Wang, X.; Evans, J.D.; Peng, W.; Chen, Y. The Prevalence of Parasites and Pathogens in Asian Honeybees Apis cerana in China. PLoS ONE 2012, 7, e47955. [CrossRef] [PubMed]

2. Van der Zee, R.; Pisa, L.; Andonov, S.; Brodschneider, R.; Charriere, J.; Chlebo, R.; Coffey, M.F.; Crailsheim, K.; Dahle, B.; Gajda, A.; et al. Managed honey bee colony losses in Canada, China, Europe, Israel and Turkey, for the winters of 2008-2009 and 2009-2010. J. Apic. Res. 2012, 51, 91-114. [CrossRef] 
3. Steinhauer, N.A.; Rennich, K.; Wilson, M.E.; Caron, D.M.; Lengerich, E.J.; Pettis, J.S.; Rose, R.; Skinner, J.A.; Tarpy, D.R.; Wilkes, J.T.; et al. A national survey of managed honey bee 2012-2013 annual colony losses in the USA: Results from the Bee Informed Partnership. J. Apic. Res. 2014, 53, 1-18. [CrossRef]

4. Van der Zee, R.; Brodschneider, R.; Brusbardis, V.; Charriere, J.; Chlebo, R.; Coffey, M.F.; Dahle, B.; Drazic, M.M.; Kauko, L.; Kretavicius, J.; et al. Results of international standardised beekeeper surveys of colony losses for winter 2012-2013: Analysis of winter loss rates and mixed effects modelling of risk factors for winter loss. J. Apic. Res. 2014, 53, 19-34.

5. Lee, K.V.; Steinhauer, N.; Rennich, K.; Wilson, M.E.; Tarpy, D.R.; Caron, D.M.; Rose, R.; Delaplane, K.S.; Baylis, K.; Lengerich, E.J.; et al. A national survey of managed honey bee 2013-2014 annual colony losses in the USA. Apidologie 2015, 46, 292-305. [CrossRef]

6. Higes, M.; Martin, R.; Meana, A. Nosema ceranae, a new microsporidian parasite in honeybees in Europe. J. Invertebr. Pathol. 2006, 92, 93-95. [CrossRef]

7. Le Conte, Y.; Ellis, M.; Ritter, W. Varroa mites and honey bee health: Can Varroa explain part of the colony losses? Apidologie 2010, 41, 353-363. [CrossRef]

8. Rortais, A.; Villemant, C.; Gargominy, O.; Rome, Q.; Haxaire, J.; Papachristoforou, A.; Arnold, G. A New Enemy of Honeybees in Europe: The Asian Hornet, Vespa velutina. In Atlas of Biodiversity Risks_From Europe to the Globe, from Stories to Maps; Settele, J., Grabaum, R., Grobelnick, V., Hammen, V., Klotz, S., Penev, L., Kühn, I., Eds.; Atlas of Biodiversity Risk; Pensoft: Sofia, Bulgaria, 2010; p. 181.

9. Martin, S.J.; Highfield, A.C.; Brettell, L.; Villalobos, E.M.; Budge, G.E.; Powell, M.; Nikaido, S.; Schroeder, D.C. Global Honey Bee Viral Landscape Altered by a Parasitic Mite. Science 2012, 336, 1304-1306. [CrossRef] [PubMed]

10. Mutinelli, F.; Montarsi, F.; Federico, G.; Granato, A.; Ponti, A.M.; Grandinetti, G.; Ferre, N.; Franco, S.; Duquesnes, V.; Riviere, M.; et al. Detection of Aethina tumida Murray (Coleoptera: Nitidulidae.) in Italy: Outbreaks and early reaction measures. J. Apic. Res. 2014, 53, 569-575. [CrossRef]

11. Iatridou, D.; Pohl, L.; Tlak Gajger, I.; De Briyne, N.; Bravo, A.; Saunders, J. Mapping the teaching of honeybee veterinary medicine in the European union and European free trade area. Vet. Rec. Open 2019, 6, e000343. [CrossRef]

12. Pettis, J. A scientific note on Varroa destructor resistance to coumaphos in the United States. Apidologie 2004, 35, 91-92. [CrossRef]

13. Rinkevich, F.D. Detection of amitraz resistance and reduced treatment efficacy in the Varroa Mite, Varroa destructor, within commercial beekeeping operations. PLoS ONE 2020, 15, e0227264. [CrossRef] [PubMed]

14. Thompson, H.; Brown, M. Is contact colony treatment with antibiotics an effective control for European foulbrood? Bee World 2001, 82, 130-138. [CrossRef]

15. Genersch, E. American Foulbrood in honeybees and its causative agent, Paenibacillus larvae. J. Invertebr. Pathol. 2010, 103, S10-S19. [CrossRef]

16. Rosenkranz, P.; Aumeier, P.; Ziegelmann, B. Biology and control of Varroa destructor. J. Invertebr. Pathol. 2010, 103, S96-S119. [CrossRef]

17. Gisder, S.; Genersch, E. Identification of Candidate Agents Active against N. ceranae Infection in Honey Bees: Establishment of a Medium Throughput Screening Assay Based on N. ceranae Infected Cultured Cells. PLoS ONE 2015, 10, e0117200. [CrossRef]

18. TECA-Technologies and Practices for Small Agricultural Producers. Available online: http://www.fao.org/teca/categories/ beekeeping/en/ (accessed on 23 July 2021).

19. Apicoltura, Produzioni e Patologie Delle Api. Available online: http:/ / www.izslt.it/apicoltura/en/ (accessed on 23 July 2021).

20. Gray, A.; Adjlane, N.; Arab, A.; Ballis, A.; Brusbardis, V.; Charriere, J.; Chlebo, R.; Coffey, M.F.; Cornelissen, B.; Amaro da Costa, C.; et al. Honey bee colony winter loss rates for 35 countries participating in the COLOSS survey for winter 2018-2019, and the effects of a new queen on the risk of colony winter loss. J. Apic. Res. 2020, 59, 744-751. [CrossRef]

21. Kulhanek, K.; Steinhauer, N.; Rennich, K.; Caron, D.M.; Sagili, R.R.; Pettis, J.S.; Ellis, J.D.; Wilson, M.E.; Wilkes, J.T.; Tarpy, D.R.; et al. A national survey of managed honey bee 2015-2016 annual colony losses in the USA. J. Apic. Res. 2017, 56, 328-340. [CrossRef]

22. Waite, R.; Brown, M.; Thompson, H.; Bew, M. Controlling European foulbrood with the shook swarm method and oxytetracycline in the UK. Apidologie 2003, 34, 569-575. [CrossRef]

23. Thompson, H.; Waite, R.; Wilkins, S.; Brown, M.; Bigwood, T.; Shaw, M.; Ridgway, C.; Sharman, M. Effects of European foulbrood treatment regime on oxytetracycline levels in honey extracted from treated honeybee (Apis mellifera) colonies and toxicity to brood. Food Addit. Contam. 2005, 22, 573-578. [CrossRef]

24. Thompson, H.; Waite, R.; Wilkins, S.; Brown, M.; Bigwood, T.; Shaw, M.; Ridgway, C.; Sharman, M. Effects of shook swarm and supplementary feeding on oxytetracycline levels in honey extracted from treated colonies. Apidologie 2006, 37, 51-57. [CrossRef]

25. Budge, G.E.; Barrett, B.; Jones, B.; Pietravalle, S.; Marris, G.; Chantawannakul, P.; Thwaites, R.; Hall, J.; Cuthbertson, A.G.S.; Brown, M.A. The occurrence of Melissococcus plutonius in healthy colonies of Apis mellifera and the efficacy of European foulbrood control measures. J. Invertebr. Pathol. 2010, 105, 164-170. [CrossRef] [PubMed]

26. Colin, M.; Vandame, R.; Jourdan, P.; Di Pasquale, S. Fluvalinate resistance of Varroa jacobsoni oudemans (Acari: Varroidae) in Mediterranean apiaries of France. Apidologie 1997, 28, 375-384. [CrossRef]

27. Elzen, P.; Baxter, J.; Spivak, M.; Wilson, W. Amitraz resistance in Varroa: New discovery in North America. Am. Bee J. 1999, 139, 362. 
28. Elzen, P.; Baxter, J.; Spivak, M.; Wilson, W. Control of Varroa jacobsoni oudemans resistant to fluvalinate and amitraz using coumaphos. Apidologie 2000, 31, 437-441. [CrossRef]

29. Milani, N.; Della Vedova, G. Decline in the proportion of mites resistant to fluvalinate in a population of Varroa destructor not treated with pyrethroids. Apidologie 2002, 33, 417-422. [CrossRef]

30. Thompson, H.; Brown, M.; Ball, R.; Bew, M. First report of Varroa destructor resistance to pyrethroids in the UK. Apidologie 2002, 33, 357-366. [CrossRef]

31. Stara, J.; Pekar, S.; Nesvorna, M.; Erban, T.; Vinsova, H.; Kopecky, J.; Doskocil, I.; Kamler, M.; Hubert, J. Detection of tau-fluvalinate resistance in the mite Varroa destructor based on the comparison of vial test and PCR-RFLP of kdr mutation in sodium channel gene. Exp. Appl. Acarol. 2019, 77, 161-171. [CrossRef]

32. Pietropaoli, M.; Mortarino, M.; Formato, G. The nightmare before Christmas: First cases of thymol resistance in Varroa destructor. In Proceedings of the 11th COLOSS Conference, Lukovica, Slovenia, 21-23 October 2015; pp. 20-24.

33. Jesus Gracia, M.; Moreno, C.; Ferrer, M.; Sanz, A.; Angel Peribanez, M.; Estrada, R. Field efficacy of acaricides against Varroa destructor. PLoS ONE 2017, 12, e0171633.

34. Garrido, C. Thymol-Varroa control. Bee Culture-The Magazine of American Beekeeping; Eastern Apicultural Society, 2018. Available online: https: / www.beeculture.com (accessed on 16 May 2021).

35. Mutinelli, F. Veterinary medicinal products to control Varroa destructor in honey bee colonies (Apis mellifera) and related EU legislation-an update. J. Apic. Res. 2016, 55, 78-88. [CrossRef] 